\title{
BLESSING OR CURSE? THE IMPACTS OF NON-AGRICULTURAL PART-TIME WORK OF THE LARGE FARMER HOUSEHOLDS ON AGRICULTURAL LABOR PRODUCTIVITY
}

\author{
Xin JIANG ${ }^{1}$, Shihu $Z \mathrm{ZHONG}^{2}$, Cancan $\mathrm{HUANG}^{3}$, \\ Xiaoxin $\mathrm{GUO}^{4}$, Jingjing $\mathrm{ZHAO}^{5}$ \\ ${ }^{1}$ School of Economics, Nankai University, 300071 Tianjin, China \\ ${ }^{2}$ Shanghai National Accounting Institute, 201799 Shanghai, China \\ ${ }^{3}$ School of Economics, Liaoning University, 110036 Shenyang, China \\ ${ }^{4}$ School of Public Economics and Administration, Shanghai University of Finance \\ and Economics, 200433 Shanghai, China \\ ${ }^{5}$ School of Law, Shanghai University of Finance and Economics, 200433 Shanghai, China
}

Received 17 September 2020; accepted 02 May 2021; first published online 11 November 2021

\begin{abstract}
This study analyzes the mechanism of coexistence of non-agricultural part-time work of farmer households and large-scale cultivation of cultivated land, and the effect of non-agricultural part-time work of the large farmer households on the agricultural labor productivity. Results indicate that non-agricultural part-time work of large farmer households promotes the agricultural labor productivity, particularly for those with higher non-agricultural incomes, younger age, higher education level and shorter distance between working places in urban sectors and rural residence. At the mean value of the samples, non-agricultural part-time work of the large farmer households will improve agricultural labor productivity by $27.1 \%$. These results remain consistent after we experiment several robustness checks and the instrumental variable method. Further, it is worth stressing that non-agricultural part-time work inhibits the agricultural production for farmer households with labors less than three, while it exhibits positive effects for those with labors more than three. Finally, analysis of mechanism suggests that non-agricultural part-time work of large farmer households enhances the productivity via entering the agricultural association, increasing farm mechanization degree, and promoting the centralized production and farm management on the transferred farmland. It's suggestive to maintain total area of the transferred farmland to avoid the reverse effects and then the optimal total cultivated area within the range of $(100,200)$ Mu. Policy implications of our work are discussed.
\end{abstract}

Keywords: non-agricultural part-time work, large farmer households, agricultural labor productivity, heterogeneity.

JEL Classification: J01, J61, O18.

${ }^{\star}$ Corresponding author. E-mail: guoxiaoxin93@163.com 


\section{Introduction}

Market economy in China has greatly progressed and provided amounting job opportunities in urban regions since the reformation and opening-up policy in 1978 (Zhang, 2014; Liu \& Shi, 2010, 2015; Qin \& Zhang, 2016; Huang et al., 2018). Meanwhile, the national background of "more farmers but less farmlands" for rural regions has further facilitated the urban employment of surplus rural labor force with the gradual liberalization of population mobility and household registration control. Typically, part-time farming has been identified as one of the most crucial factors enhancing the coordinated development of urban and rural economy during the urbanization (Lewis, 1954; Lu, 2012; Liang et al., 2013). However, it should be noted that in the process of China's population urbanization, there is a significant population flow characteristic for rural farmers to be engaged in non-agricultural part-time work during slack time (Zhao \& Jiang, 2015; Zhao et al., 2020). According to the monitoring data in 2015, proportions of the farmers engaged in full-time and part-time farming, the nonagricultural citizens involved in part-time farming and the non-farming citizens were $10.3 \%$, $11.6 \%, 20.6 \%$ and $57.5 \%$, respectively. Meanwhile changing tendency towards the large-scale agricultural production has been highlighted as the deepening reform of the transfer system of rural farmland (Zhao \& Jiang, 2015; Wang et al., 2016). So it's imperative to illustrate the effect of non-agricultural part-time work of the large farmer households on agricultural labor productivity, which benefits for distinguishing the changing characteristics of the influential paths associated with the development trend of Chinese agricultural production in future.

A large number of studies have been conducted to qualitatively or quantitatively investigate the representative characteristic of rural farmers engaged in non-agricultural part-time work and its potential impacts on agricultural production. From the perspective of scale economy of agricultural production, some qualitative studies consider that non-agricultural part-time work of farmer households restricts the expansion of farmland scale and the improvement of economic efficiency of small-scale peasants, which is not conducive to the improvement of agricultural labor productivity (Kawagoe et al., 1985; Xu, 1995; Huang, 2003; Zhao, 2014; Zhao \& Jiang, 2015). However, these research can't fundamentally explain why the phenomenon of non-agricultural part-time work of farmer households has existed for a long time in China while agricultural labor productivity is continuously increasing, nor can it provide strong theoretical supports for the existence of economies of scale of agricultural production. In terms of the labor division and specialization, the non-agricultural part-time work of farmer households is conducive to optimizing the labor-force allocation (Nguyen et al., 2019) and then deepening the labor specialization for agricultural production. In addition, the yearly income from the non-agricultural part-time work motivates farmers to selectively purchase modern agricultural production machines (Qiu et al., 2020), or increase the fertilizer and pesticide expenditures (Ma et al., 2018), to improve the agricultural labor productivity in the roundabout production pattern (Xiang \& Han, 2005; El Omari, 2017; Tang et al., 2019).

The above theoretical research on the perspective of agricultural production division broadens the research horizon for this paper. So we think that under the background of small-scale peasant economic production brought about by the household contract respon- 
sibility system, it is the non-agricultural part-time work of farmer households that promotes the deepening of the division of labor in both of urban and rural sectors (Zhao et al., 2020), thus bringing about the economic benefits of specialization of agricultural production, which can explain the continuous promotion of the agricultural labor productivity in the past 40 years in China. However, although the mode of agricultural production of this family smallscale peasant economy has greatly improved agricultural labor productivity in China, the overall level is still low (Gao, 2015; Wang et al., 2017), and it has been difficult to meet the rapidly expanding market demand for agricultural products (Zhao, 2014), while the division of labor and the improvement of specialization level of family agricultural production are the necessary conditions for expanding the market demand of agricultural products (Young, 1928; Yang, 2003). Therefore, under the background of deepening the division of labor in large-scale production at home and abroad, the implementation of large-scale cultivation of cultivated land is an inevitable trend to deepen the division of labor and the level of specialization in agricultural production in China and to promote the development of agricultural modernization. However, whether non-agricultural part-time work of farmer households can coexist with large-scale cultivation of cultivated land?

Based on the above analysis, this study uses theoretical analysis and the micro-survey data of 418 farmer households from the seven major crop-growing counties (or county-level cities) in Hunan Province to examine that how non-agricultural part-time work of farmer households impacts its agricultural labor productivity under the large scale management of farmland.

The main contributions of this study can be summarized in the following four aspects. First, for research perspective, the authors analyze the mechanism of coexistence of nonagricultural part-time work of farmer households and large-scale cultivation of cultivated land, and the effect of non-agricultural part-time work of the large farmer households on the agricultural labor productivity.

Second, in terms of methodologies, the authors mainly employ the micro-survey data from 418 farmer households in Hunan province, central China to identify the above working mechanisms. The authors also adopt identification strategies like two-stage least square method (2SLS), two stage generalized method of moments (2SGMM) and the two stage limited information maximum likelihood estimation (2SLILM). Moreover, a series of robustness checks including replacing the explained variable, replacing the key explanatory variable, and changing estimation method are conducted. Estimate bias caused by the endogeneity such as reverse causality and omission of variables can therefore be avoided.

Third, due to variance in the total farmland area of farmer households, age of farmer households, education experience of farmer households, and number of labor force engaged in agricultural production, the authors study the heterogeneity which exists in the impacts of non-agricultural part-time work of the large farmer households on its agricultural labor productivity.

Fourth, the authors explain how non-agricultural part-time work of the large farmer households impacts the agricultural labor productivity from three aspects: entering the agricultural association, increasing farm mechanization degree, and promoting the centralized production and farm management on the transferred farmland. 
It has great significance to illumine the impact of non-agricultural part-time work in the agricultural productivity and whether characteristics of different farmer households and respective family conditions affect this impact. The remainder of the paper is organized as follows. Section 1 provides a two-level academic hypothesis based on the institutional background and literature review of the relevant topics. Section 2 is the research design, which includes sample selection, data source, variable definition, empirical strategy and model setting. Section 3 provides the empirical results, applies a series of robustness check, explores the heterogeneity across sub-samples and employs mechanism test. We conclude in the last section and propose the policy implications.

\section{Theoretical analysis and hypothesis}

Against the backdrop of farmland transfer in rural area, the large scale management of farmland has gradually become the trend of agricultural production in China. Following the economic theory of division of labor (Yang, 1994, 2003; Xiang \& Han, 2005), the three working mechanisms could be proposed to illustrate the above question, including the labor specialization, economical organization and circuitous production. Firstly, the rational allocation of the labor force and the supplied labor time per capita within farmer households would strengthen the organic combination of labor specialization of farmer households to obtain the win-win promotion of the overall labor productivity in both the rural and urban sectors during the busy and slack farming seasons. Secondly, the non-agricultural part-time work of farmer households would endogenously generate demands for the spontaneous construction and participation of agricultural mutual aid and the cooperative association. Thirdly, non-agricultural part-time work of farmer households will increase the yearly income and actively push the purchase of modern agricultural machines, and thus saving the labor-time in agricultural production. In general, non-agricultural part-time work of farmer households would positively improve the agricultural labor productivity through deepening the degree of specialization and the division of labor to gain the benefits of specialized economies. Detailed illumination is shown below.

\subsection{Why would farmer households select non-agricultural part-time work under the large scale management of farmland?}

Three aspects should be taken into consideration for farmer households' switching from fulltime agricultural production to part-time farming: definition of part-time farming, natural property of agricultural production, and the "push-pull" effect between agricultural sector and non-agricultural sector.

Part-time farming of farmer households refers to the fact that farmer households engage in agricultural production according to seasonal cycle and participate in non-agricultural work in free time (usually in certain months or periods of time) (Qian, 2003; Zhao, 2014). This constitutes the foundation for domestic labor division theory which maintains that nonagricultural part-time work of farmer households affects family-based agricultural labor productivity. 
The natural property of agricultural production is the primary cause for farmer households to be engaged in non-agricultural part-time work during slack time. For that, this study holds: first, agricultural production showcases an obvious seasonal cycle. During busy farming season, labors at a farmer households and their time will be devoted into specialized agricultural production while during slack season, family labor time per unit required and consumed for agricultural maintenance is less in comparison. The farmer households therefore can optimize distribution of the total labor time supply among agricultural and non-agricultural activities. Optimal distribution of labor element among urban and rural sector can help improve productivity in both agricultural and non-agricultural sector (Gai et al., 2017); second, market risks of agricultural operation is far higher than other industries. Coupled with natural risks, agricultural output is volatile. All of these result in unstable agricultural earnings. In order to mitigate the risk and loss of agricultural production, largescale farmer households are highly probable to work part-time at other places (Zhao, 2014).

In addition, agricultural production can help meet the basic needs of life for farmer households. Relevant features of agricultural production such as additional economic earnings through agricultural subsidies galvanize farmer households to retain partial farmland and go other places for part-time job (Xu, 2010); third, it is worth emphasizing that it was in 2014 that rural farmland transfer was implemented across the board. At current stage, the large scale management of farmland is still an exploratory endeavor. During scale production based on farmer households, it is vital for scale farming household to realize optimal distribution of family labor and labor time between full-time agricultural production and part-time non-agricultural work. As it can not only mitigate operation risks of the large scale management of farmland effectively but promote utilization of modern agricultural machinery in scale production (Zhao, 2014). Micro-survey data analysis of this study also shows that it is a prevalent phenomenon for large-scale farmer households to select non-agricultural part-time work in cities under the background of the large scale management of farmland.

The push-pull effect of agricultural and non-agricultural sector constitutes the second cause for non-agricultural part-time work of farmer households. Classic push-pull theory divides factors impacting migration into push force and pull force. Agricultural sector is often considered to contain push factors while pull factors mainly reside in urban nonagricultural sector in analysis of flow of labor element in urban and rural sector (Zou, 2005). For agricultural production sector, under the large scale management of farmland, farmer households are pushed to find part-time jobs at other places because large-scale farmland transfer result in huge amount of labor surplus in rural area. Going to cities for other means of living becomes a rational choice for those surplus labor (Lewis, 1954; Ranis \& Fei, 1961). But employment of non-agricultural sector is unstable and labor condition is undesirable. Besides, farmer households are fascinated about stable material supply of agricultural production. All of these give rise to non-agricultural part-time work of farmer households, which is an optimal choice for them (Xiang \& Han, 2005; Zhao, 2014).

For non-agricultural sector, under the large scale management of farmland, the pull effect delivers on farmer households because prosperity of urban non-agricultural sector generates more jobs and opportunities (Liu \& Shi, 2015; Huang et al., 2018), which brings about higher non-agricultural part-time income relative to agricultural production. This is the direct cause 
for farmer households to work part-time in cities (Todaro, 1969; Zhong et al., 2016). Meanwhile, when farmers choose to the non-agricultural part-time work in cities, they will acquire more advanced agricultural production technologies and farmland management knowledge in cities, which is because of the formation of knowledge spillover effect (Glaeser, 2010). This constitutes a significant pillar for large-scale production based on modern agricultural machinery and farmland transfer. The above-mentioned push-pull effect at urban and rural sector determines that non-agricultural part-time job is a rational choice of farmer households under the large scale management of farmland. We therefore propose the first hypothesis:

Hypothesis 1. Engaging in non-agricultural part-time work during slack time remains a rational choice for farmer households under the large scale management of farmland. Non-agricultural part-time work of farmer households and family-based large scale management of farmland can co-exist.

\subsection{How does non-agricultural part-time work of farmer households affect its agricultural labor productivity under the large scale management of farmland?}

Existing research fails to reach a consensus on the relation between non-agricultural parttime work of farmer households and agricultural labor productivity (Xiang \& Han, 2005; Zhao, 2014). This study attempts to, from the perspective of domestic division of labor, examine the potential impact of part-time work of the large farmer households on family-based agricultural labor productivity and its working mechanism.

Based on agricultural production and division of labor theory, this study holds that nonagricultural part-time work of farmer households is conducive to improvement of familybased agricultural labor productivity. According to labor division theory in economics, division of labor, which includes labor specialization, diversification, organized economy, and roundabout production, represents a vital source for economic development. Increments of economic benefits brought by increasing returns and efficiency improvement can be obtained through higher transaction efficiency, which elevates the degree of labor specialization, diversification, organized economy, and roundabout production (Yang, 2003; Xiang \& Han, 2005; Narayan \& Sun, 2007). Based on this theory, the study argues that: first, rational distribution of domestic labor and individual's labor time supply among agricultural and non-agricultural sector in busy and slack season will lead to the organic combination between labor specialization and diversification of employment of individual farmers and family labor against the backdrop of the large scale management of farmland, facilitating win-win betterment of overall labor productivity in dual-track sector in both rural and urban area; second, under the large scale management of farmland, non-agricultural part-time work of farmer households will endogenously generate strong demand for establishment of and participation in agricultural co-operatives. Optimal integration of distribution of labor production element can promote agricultural labor productivity, which is the inherent requirement of the large scale management of farmland under farmland transfer; third, non-agricultural part-time work of farmer households increases the total income of the household. Farmer households is therefore more willing to buy modern agricultural machinery. 
At the meantime, non-agricultural part-time work reduces the labor time spent in agricultural production. Under production condition of the large scale management of farmland, farmer households have to purchase modern agricultural machinery. Therefore, non-agricultural part-time work facilitates, proactively or passively, the purchase of modern agricultural machinery (Wang et al., 2016), improving the degree of roundabout production of familybased the large scale management of farmland. This will deepen agricultural division of labor and elevate specialization level. In addition, advanced machinery equipment and technology brought by non-agricultural part-time work promotes the large scale management of farmland under farmland transfer. To summarize, non-agricultural part-time work of farmer households under scale operation is conducive to deepening of agricultural division of labor and specialization. Further, benefits of specialized agricultural production can be achieved, improving family-based agricultural labor productivity.

Based on the above theoretical analysis, this study believes that non-agricultural part-time work of farmer households can affect family-based agricultural labor productivity through labor specialization, organized economy, and roundabout production under the large scale management of farmland. In empirical analysis, this study selects proxy variables to conduct relevant research. First, labor specialization in agricultural production corresponds to two indicators in econometric empirical analysis, that is, "centralized production" and "familybased farm management". Because centralized production of farmland is conducive to farmers as they can choose the centralized farmland for production and avoid farming efficiency loss caused by fragmented farmland. Family-based farm management model can help realize unified modern operation and management during the whole process of agricultural production. The above mentioned measures can promote specialization of agricultural production of farmer households, motivating the desire for scale operation; moreover, non-agricultural part-time work of farmer households can help deepen labor division in agricultural production through organized agricultural production, which corresponds to "joining agricultural association" in econometric empirical analysis. This is conducive to optimal distribution of element resources among organizations. The strength of organization facilitates labor division in agricultural production and improves family-based agricultural labor productivity; last, non-agricultural part-time work of farmer households helps deepen labor division in agricultural production via roundabout agricultural production, which finds its expression in utilization of modern agricultural machinery. This will boost agricultural productivity by obtaining benefits of economies of specialization. Based on these, we propose the second hypothesis:

Hypothesis 2. Non-agricultural part-time work of farmer households is conducive to the improvement of family-based agricultural labor productivity under the large scale management of farmland through "centralization of transferred farmland", "family-based farm management", "joining agricultural association", and "improving mechanization degree". 


\subsection{Do heterogeneous exist in the impacts of non-agricultural part-time work of farmer households on agricultural labor productivity?}

Whether the impact of non-agricultural part-time work of farmer households on agricultural labor productivity vary due to the differences in actual production condition? Existing research reveals that expansion of farming land by farmer households against the backdrop of farmland transfer helps realize the economies of scale effect and promote income rise for farmers. Therefore, family-based large scale management of farmland is the must-taken road for agricultural modernization (Xu, 1995; Huang, 2003; Zhang, 2010). But under familybased farmland transfer production structure, there is an optimal distribution ratio of agricultural labor time to total farmland area. When farmers choose to the non-agricultural part-time work in cities, farmland area for transfer is not necessarily the larger the better (Wang et al., 2017). Therefore, when the farmland area for transfer is different, the extent to which non-agricultural part-time work of farmer households affects agricultural labor productivity may vary. With particular note, when farmland area exceeds certain threshold value, part-time work at other places by farmer households may be detrimental to agricultural labor productivity. Meanwhile, labor age is an important factor affecting labor productivity as cities and towns can provide more low-end and intensive labor jobs for younger migrant workers with low educational attainment and skills (Zhao, 2014; Liu \& Shi, 2005; Lu et al., 2012). Therefore, it is natural for young farmers with physical advantage to select the non-agricultural part-time work in cities. Furthermore, they are more likely to be positively influenced by spillover effect of knowledge in cities, acquire production technologies and advanced management experience in cities when farmers select the non-agricultural part-time work in cities, and put them into practice in agricultural production. Therefore, compared with elder farmers working part-time in cities, young farmers can improve labor productivity of family-based agricultural at larger scale.

Moreover, the level of human capital also imposes a major impact on labor productivity (Jiang \& Huang, 2019). When selecting the non-agricultural part-time work in cities, farmers with higher educational attainment are more capable in learning, receiving, and mastering relatively advanced production technique at their working place and mastering the operation and utilization of modern agricultural machinery. Therefore, as modernization level of agricultural production improves, educational attainment of farmers plays an increasingly important role in the large scale management of farmland. The impact of non-agricultural part-time work on agricultural labor productivity by farmers with varied educational attainment differs. Last, farmer households are the operation unit of the large scale management of farmland, in which the number of labor constitutes the precondition for farmer households' part-time decision. When the number of labor engaging in agricultural production at farmer households differs, the impact of non-agricultural part-time work of farmer households on agricultural production also varies. Based on these, we propose the third hypothesis:

Hypothesis 3. The impact of non-agricultural part-time work of farmer households on agricultural labor productivity may vary due to variances in the area of transferred farmland, age of part-time farmers, educational attainment of part-time farmers, and the number of labor engaging in agricultural production at the farmer households. 


\section{Materials and methods}

\subsection{Sampling data}

From Aug. to Oct. 2008, a field survey was conducted among the top seven rice-producing counties (Ningxiang, Xiangtan, Taoyuan, Jinshi, Dingcheng, Hanshou and Hengyang) in Hunan province, central China, containing 418 farmer households from 194 villages of 34 townships. According to the sample questionnaire survey through the face-to-face method, we randomly selected ca. 70 farmer households from each county with $94.03 \%$ large-scale farmer households in total. Mean value of farmers' family-owned and -transferred arable land was 7.6 and $176.3 \mathrm{Mu}$, respectively, that is the total area of farmland for farmer households equaled to $183.9 \mathrm{Mu}$. Intrinsically, the sample survey data exhibited the practical significance similar with the scale production of farmlands and the agricultural modernization as with the transfer system. Furthermore, the vast majority of respondents referred to heads of farmer households, and other family members owning a considerable impact on household agricultural production were selected when the farmer households was out. A total of 430 questionnaires were issued for this micro-survey, and after excluding the non-agricultural production decision makers and ineffective producers (for example, the questionnaires were filled out by juveniles and/or adults without working ability), a total of 418 valid questionnaires were recovered with an effective recovery rate of $97.21 \%$.

\subsection{Variables setting and descriptive statistics}

\subsubsection{Dependent variables}

Agricultural labor productivity of farmer households (ln falacity) is the key dependent variable expressed as followed:

$$
\ln \text { falacity }=\log \left(\frac{R}{L}\right),
$$

where: $R$ stands for the average yearly rice output and $L$ for the total labor forces of the rural family engaged in agricultural production.

In addition, "In falacity" will be replaced by the new variable "ln favincom" to test the robustness, as calculated by:

$$
\ln \text { favincom }=\log \left(\frac{I}{N}\right),
$$

where: $I$ stands for the total yearly income and $N$ for the total number of the professional farmers of farmer households.

\subsubsection{Independent variables}

\subsubsection{Key independent variable}

"Whether farmers involved in non-agricultural part-time work" (jianyeor) was identified as the key independent variable corresponding to "Do you engage in other work besides rice planting now?" in the questionnaire. And two options, i.e. "only engage in rice planting" and "not engage in non-agricultural part-time work", were offered and scored as 0 . Another three comments, i.e. "having other jobs but not full-time work", "entering into cities to work" and 
"entering into cities to work temporarily" were provided and scored as 1. Answer to "The yearly income of farmers working temporarily in urban sectors" (outincome) in the questionnaire had specific continuous values. Workplace is intended to refer to the place (such as a shop or factory) where work is done, but in this paper is to refer to the distance from working city to rural family. It is measured by the five options in the questionnaire, including local township scored as 1 , local county as 2 , local city as 3 , local province as 4 , and other provinces as 5 . The larger score indicated the longer distance between farmers' working places and the rural residence.

\subsubsection{Control variables}

Considering the inverted " $U$ " impact of worker's age (age) on the labor productivity, the age square term (age2) of farmers was supplemented in the sample questionnaire. And the education level of farmers (education) was represented by five options, i.e. no schooling scored as 1 , primary school as 2, junior middle school as 3, senior middle schools/technical secondary school as 4 , and college and beyond as 5 . Larger numerical values referred to the higher education level of farmers. Longer-term rice planting (riceyear) reflected farmer's greater experience on rice planting and then the higher productivity during agricultural production. In the sample questionnaire, two options, i.e. yes scored as 1 and no as 0 , were used to define "Whether the agricultural production is dependent on family farm" (jtnchangor), "Join rice cooperative association or not" (groupor), and "Whether the model of farmer households or not" (ricesfhu). As for the variable "Rice certified or not?" (proveor), comments included "pollution-free certification", "green certification" and/or "organic certification" scored as 1 and "no certification" scored as 0 .

"Area of farmlands transferred from other farmers" (lzhuanland), "The number of family farmland plots" (landkshu), "The years of contract signed on farmland transferred" (liuzhyear), and "The price of farmland transferred" (liuzhprice) are all important factors that affect farmers' enthusiasm for grain production and then the productivity.

Among variables of total investment of seedling per $\mathrm{Mu}(\ln z$ mtinput), fertilizer and pesticide per $\mathrm{Mu}$ (ln hxfyaoinput), mechanized harvest and irrigation per $\mathrm{Mu}$ (ln jqsyinput) and labor employment per $\mathrm{Mu}$ (ln yongjinput), the first three items were defined as the material capital investment and the forth item as the labor factor investment, all of which directly affect the agricultural labor productivity of farmer households. In addition, total subsidies for protecting the farmland productivity (totalgdsubsi), supporting the scale planters (totaldhsubsi) and purchasing the agricultural machinery (nongjisubsi) were encompassed as for policy variables affecting agricultural labor productivity. "Whether to plant other crops other than rice" (otherplants) was defined with "only planting rice" scored as 0 and "other cash crops"/ "main cash crops" as 1.

\subsubsection{Instrumental variables}

The key independent variable jianyeor would generate endogenous problems and then biased results during the econometric regression. Hence it's prerequisite to determine the exogenous instrumental variables. "Have you ever been engaged in any other profession before?" (otherjobor) is specified in the questionnaire with comments "yes" scored as 1 and "no" as 0 to represent the exogenous instrumental variable for jianyeor.

The meaning and descriptive statistics of related variables are shown in Table 1. 
Table 1. Descriptive statistics of key variables

\begin{tabular}{|c|c|c|c|c|c|}
\hline Name & Economic meaning & Mean & $\mathrm{Sd}$ & Minimum & Maximum \\
\hline $\ln$ falacity & $\begin{array}{l}\text { Agricultural labor productivity of farmer } \\
\text { households (kg/person) }\end{array}$ & 10.92 & 1.351 & 7.090 & 14.89 \\
\hline ln favincom & $\begin{array}{l}\text { The average yearly income of the permanent } \\
\text { rural residents of farmer households (ten } \\
\text { thousand yuan/person) }\end{array}$ & 1.512 & 1.148 & -2.081 & 5.538 \\
\hline jianyeor & Whether farmers to cities to work temporarily & 0.562 & 0.497 & 0 & 1 \\
\hline outincome & $\begin{array}{l}\text { The average yearly income of farmers working in } \\
\text { urban sectors temporarily (ten thousand yuan) }\end{array}$ & 0.798 & 2.026 & 0 & 20 \\
\hline workplace & $\begin{array}{l}\text { The distance from the working city to rural } \\
\text { family }\end{array}$ & 1.488 & 1.641 & 0 & 5 \\
\hline age & The age of farmers & 5.189 & 0.805 & 2.9 & 7.7 \\
\hline education & The education years of farmers & 3.136 & 0.801 & 1 & 5 \\
\hline noyerk & $\begin{array}{l}\text { The number of farmers engaged in agricultural } \\
\text { production in farmer households }\end{array}$ & 2.349 & 0.963 & 1 & 6 \\
\hline riceyear & The years of rice planting & 19.94 & 13.26 & 1 & 55 \\
\hline jtnchangor & Whether relied on family farm for agriculture & 0.694 & 0.461 & 0 & 1 \\
\hline groupor & Whether joined rice cooperative association & 0.435 & 0.496 & 0 & 1 \\
\hline ricesfhu & Whether the official model of farmer households & 0.467 & 0.499 & 0 & 1 \\
\hline proveor & Whether rice certified or not & 0.096 & 0.295 & 0 & 1 \\
\hline selfland & $\begin{array}{l}\text { The area of farmers' family-owned farmland } \\
\text { (Mu) }\end{array}$ & 7.602 & 7.358 & 1.2 & 50 \\
\hline lzhuanland & $\begin{array}{l}\text { The area of farmlands transferred from other } \\
\text { farmers }(100 \mathrm{Mu})\end{array}$ & 1.763 & 2.277 & 0 & 12 \\
\hline landkshu & The number of family farmland plots & 15.78 & 18.31 & 1 & 83 \\
\hline liuzhyear & $\begin{array}{l}\text { The years of contract signed on farmland } \\
\text { transferred }\end{array}$ & 4.450 & 2.611 & 0 & 15 \\
\hline liuzhprice & The price of farmland transferred (100 yuan) & 2.558 & 1.325 & 0 & 5.2 \\
\hline $\ln$ zmtinput & Total input of seedling Per $\mathrm{Mu}$ (yuan/Mu) & 4.558 & 0.699 & 2.303 & 5.953 \\
\hline $\ln$ hxfyaoinput & $\begin{array}{l}\text { Total input of fertilizer and pesticide Per } \mathrm{Mu} \\
\text { (yuan/Mu) }\end{array}$ & 5.798 & 0.381 & 4.382 & 6.703 \\
\hline $\ln$ jqsyinput & $\begin{array}{l}\text { Total input of mechanical harvesting and } \\
\text { irrigation Per } \mathrm{Mu} \text { (yuan/Mu) }\end{array}$ & 6.031 & 0.242 & 5.011 & 6.646 \\
\hline $\ln$ yongjinput & $\begin{array}{l}\text { Total input of labor employment Per } \mathrm{Mu} \\
\text { (yuan/Mu) }\end{array}$ & 4.316 & 0.639 & 3.188 & 5.979 \\
\hline totalgdsubsi & $\begin{array}{l}\text { The total subsidies for the protection of farmland } \\
\text { productivity ( } 10 \text { thousand yuan) }\end{array}$ & 0.105 & 0.111 & 0.013 & 0.875 \\
\hline totaldhsubsi & $\begin{array}{l}\text { The total subsidies for scale planters of rural } \\
\text { family ( } 10 \text { thousand yuan) }\end{array}$ & 1.452 & 2.811 & 0 & 20.23 \\
\hline nongjisubsi & $\begin{array}{l}\text { The total subsidies for the purchase of household } \\
\text { agricultural machinery ( } 10 \text { thousand yuan) }\end{array}$ & 0.152 & 0.295 & 0 & 2.124 \\
\hline otherplants & Whether to plant other crops other than rice & 0.352 & 0.478 & 0 & 1 \\
\hline otherjobor & $\begin{array}{l}\text { Whether have ever been engaged in any other } \\
\text { profession before }\end{array}$ & 0.661 & 0.474 & 0 & 1 \\
\hline fntime & $\begin{array}{l}\text { How long have you been in non-farm } \\
\text { employment before }\end{array}$ & 4.684 & 5.633 & 0 & 35 \\
\hline
\end{tabular}

Notes: (1) The symbol "In" prefixing several variables above means taking logarithm; (2) All digits retain up to four valid digits, the same below. 


\subsection{Econometric model}

Considering the mean area of farmers' family-owned and transferred farmlands were respectively 7.6 and 176.3 Mu with the corresponding maximums as 50 and $200 \mathrm{Mu}$, it's evident that impacts of non-agricultural part-time work of the large farmer households on agricultural labor productivity might be varied with the wide range of farmland area. Furthermore, control variables, including age, education and noyerk, were characterized by the broad numerical range, suggesting the above impacts distinct with those influential factors. Overall, features of the data structure sustained the subsequent analysis on the differentiated impacts of nonagricultural part-time work of the large farmer households on agricultural labor productivity with efficient micro-data.

The following econometric regression model was adopted to evaluate effects of jianyeor on ln falacity:

$$
\ln \text { falacity }_{i}=C+\partial_{1} \text { jianyeor }_{i}+\sum_{j=1} \beta_{j} X_{j}+u_{i},
$$

where: $X_{j}$ stands for a set of control variables affecting $\ln$ falacity as detailed in Table 1 . And $u_{i}$ is an error term.

\section{Results and discussion}

\subsection{Benchmark and robustness test}

By taking the cluster robust standard error, the standard empirical regression results were listed in the first column of Table 2 . To further validate the robustness and credibility, the regression process of first column was re-conducted, results of which were listed in the second row with "In favincom" taken as the explained variable. Subsequently, we utilized outincome as the key explanatory variable and $\ln$ falacity as the explained variable to obtain the regression results in the third column by repeating the relevant regression process of the former two columns with the data of the yearly average income of a certain farmer working in cities temporarily higher than zero (235 samples in total). To illustrate how the spatial distance from working place to rural family impacts the agricultural labor productivity of farmer households, we utilized workplace as explanatory variable and ln falacity as the explained variable and then repeated the relevant regression process of the former three columns to obtain results in the fourth row. Finally, considering the possible heteroscedasticity of crosssectional data, we re-performed the regression process of the first column in Table 2 with the Weighted Least Square (WLS) method, and obtained results in the fifth column.

The coefficient of the variable jianyeor in the first column is a positive value of 0.271 $(p<0.01)$, that is, at the mean value of the samples, non-agricultural part-time work of the large farmer households will improve agricultural labor productivity by $27.1 \%$. Which indicates that non-agricultural part-time work of the large farmer households significantly exerted a positive effect on agricultural labor productivity. It was consistently demonstrated in the second column by replacing $\ln$ falacity with $\ln$ favincom for jianyeor still processing a positive value of $0.249(p<0.05)$, indicating that the average yearly income of farmers could 
be positively increased due to the non-agricultural part-time work. As with the contract responsibility institution for farmlands in China since 1978, the confined area of arable land for certain rural family was inadequate to sustain the livelihood. Then it's rational for farmers to participate in the non-agricultural part-time work, further deepening the labor division and specialization during the agricultural production and elevating the agricultural labor productivity via the economical organization and circuitous production.

Along with the reform of transfer system in 2014, both the transferred area of arable land and the planting scale of farmer households were greatly increased. Then it's of importance to ascertain whether the non-agricultural part-time work of the large farmer households still promotes the agricultural labor productivity and then the potential promotion exerts certain scale threshold effect on farmland area. Significant coefficients of the third and fourth columns for the core explanatory variables indicated that higher yearly income from the non-agricultural part-time work was conducive to improving the agricultural labor productivity, but longer working distance would inhibit it. Consequently, we recommended that the urban should be equipped with critical industries to support farmers engaged in the part-time employment locally or nearby and facilitate the development of large-scale agricultural production, then realizing the win-win economic development. As indicated in the fifth column, results of the regression analysis were still robust and credible even though considering possible heteroscedasticity.

Table 2. The impact of non-agricultural part-time work of farmer households on agricultural labor productivity

\begin{tabular}{|c|c|c|c|c|c|}
\hline \multirow{2}{*}{ Variables } & (1) & (2) & (3) & (4) & (5) \\
\hline & $\ln$ falacity & In favincom & $\ln$ falacity & $\ln$ falacity & WLS mode \\
\hline \multirow{2}{*}{ jianyeor } & $0.271^{\star \star \star}$ & $0.249^{\star *}$ & & & $0.242^{\star \star}$ \\
\hline & $(0.101)$ & $(0.115)$ & & & $(0.105)$ \\
\hline \multirow{2}{*}{ outincome } & & & $0.153^{\star *}$ & & \\
\hline & & & $(0.069)$ & & \\
\hline \multirow{2}{*}{ workplace } & & & & $-0.284^{* * *}$ & \\
\hline & & & & $(0.059)$ & \\
\hline \multirow{2}{*}{ age } & $0.559^{* *}$ & $0.905^{*}$ & $0.728^{*}$ & $0.432^{\star *}$ & $0.687^{\star}$ \\
\hline & $(0.251)$ & $(0.467)$ & $(0.466)$ & $(0.209)$ & $(0.376)$ \\
\hline \multirow{2}{*}{ age 2} & $-0.0593^{\star *}$ & $-0.0931^{\star *}$ & $-0.0836^{*}$ & -0.0477 & $-0.0674^{*}$ \\
\hline & $(0.0295)$ & $(0.0458)$ & $(0.0433)$ & $(0.0387)$ & $(0.0419)$ \\
\hline \multirow{2}{*}{ education } & $0.117^{\star}$ & $0.0721^{\star *}$ & $0.0798^{\star *}$ & $0.117^{* *}$ & $0.0958^{\star *}$ \\
\hline & $(0.0628)$ & $(0.0332)$ & $(0.0375)$ & $(0.0595)$ & $(0.0464)$ \\
\hline \multirow{2}{*}{ riceyear } & $0.0141^{\star * *}$ & $0.0093^{\star * *}$ & $0.0093^{\star *}$ & $0.0129^{* * *}$ & $0.011^{* * *}$ \\
\hline & $(0.0033)$ & $(0.0034)$ & $(0.0043)$ & $(0.0031)$ & $(0.0037)$ \\
\hline \multirow{2}{*}{ jtnchangor } & $0.459^{* * *}$ & $0.324^{* * *}$ & $0.680^{* *}$ & $0.347^{* * *}$ & $0.247^{\star}$ \\
\hline & $(0.110)$ & $(0.112)$ & $(0.333)$ & $(0.113)$ & $(0.132)$ \\
\hline
\end{tabular}


End of Table 2

\begin{tabular}{|c|c|c|c|c|c|}
\hline \multirow{2}{*}{ Variables } & (1) & (2) & (3) & (4) & (5) \\
\hline & $\ln$ falacity & ln favincom & $\ln$ falacity & $\ln$ falacity & WLS model \\
\hline \multirow{2}{*}{ groupor } & $0.0764^{\star *}$ & $0.108^{*}$ & $0.195^{*}$ & 0.0734 & $0.149^{\star *}$ \\
\hline & $(0.0379)$ & $(0.062)$ & $(0.119)$ & $(0.0888)$ & $(0.067)$ \\
\hline \multirow{2}{*}{ ricesfhu } & $0.308^{\star * *}$ & $0.263^{\star * *}$ & $0.299^{\star *}$ & $0.261^{\star * *}$ & $0.304^{\star * *}$ \\
\hline & $(0.0964)$ & $(0.0924)$ & $(0.121)$ & $(0.0911)$ & $(0.106)$ \\
\hline \multirow{2}{*}{ proveor } & $0.0422^{\star * *}$ & $0.0391^{*}$ & 0.0311 & 0.0303 & $0.0454^{\star *}$ \\
\hline & $(0.013)$ & $(0.025)$ & $(0.024)$ & $(0.030)$ & $(0.017)$ \\
\hline \multirow{2}{*}{ lzhuanland } & $0.0062^{\star \star \star}$ & $0.0038^{\star \star *}$ & $0.0086^{\star * *}$ & $0.0056^{\star \star \star}$ & $0.0076^{* * *}$ \\
\hline & $(0.0011)$ & $(0.0011)$ & $(0.0017)$ & $(0.0011)$ & $(0.0013)$ \\
\hline \multirow{2}{*}{ landkshu } & $-0.0079^{\star \star \star}$ & $-0.0064^{\star \star}$ & $-0.0115^{\star \star \star}$ & $-0.0072^{\star \star \star}$ & $-0.0102^{\star * *}$ \\
\hline & $(0.0027)$ & $(0.0029)$ & $(0.0042)$ & $(0.0027)$ & $(0.0034)$ \\
\hline \multirow{2}{*}{ liuzhyear } & $0.094^{\star \star \star}$ & $0.0691^{\star * *}$ & $0.108^{\star \star \star}$ & $0.0942^{\star \star \star}$ & $0.105^{\star * *}$ \\
\hline & $(0.0207)$ & $(0.0183)$ & $(0.0279)$ & $(0.0196)$ & $(0.0244)$ \\
\hline \multirow{2}{*}{ liuzhprice } & $0.0014^{\star * \star}$ & 0.0005 & $0.0016^{* * *}$ & $0.0011^{\star \star \star}$ & $0.0015^{\text {} * \star}$ \\
\hline & $(0.0004)$ & $(0.0003)$ & $(0.0006)$ & $(0.0004)$ & $(0.0005)$ \\
\hline \multirow{2}{*}{$\ln z m t i n p u t$} & $0.308^{\star \star \star}$ & $0.210^{\star \star \star \star}$ & $0.323^{\text {***}}$ & $0.297^{\star \star \star}$ & $0.313^{* * *}$ \\
\hline & $(0.0722)$ & $(0.0678)$ & $(0.0995)$ & $(0.0700)$ & $(0.0842)$ \\
\hline \multirow{2}{*}{$\ln$ hxfyaoinput } & $0.217^{\star}$ & $0.235^{\star}$ & 0.243 & 0.159 & 0.232 \\
\hline & $(0.123)$ & $(0.124)$ & $(0.161)$ & $(0.120)$ & $(0.142)$ \\
\hline \multirow{2}{*}{ ln jqsyinput } & $0.858^{\star * *}$ & $0.662^{\star * \star}$ & $0.868^{\star \star}$ & $0.809^{* * \star}$ & $0.845^{\star * \star}$ \\
\hline & $(0.227)$ & $(0.202)$ & $(0.345)$ & $(0.220)$ & $(0.279)$ \\
\hline \multirow{2}{*}{$\ln$ yongjinput } & $0.0623^{* *}$ & $0.0503^{\star}$ & 0.0769 & 0.0392 & $0.0784^{\star \star}$ \\
\hline & $(0.0311)$ & $(0.0329)$ & $(0.101)$ & $(0.0704)$ & $(0.0344)$ \\
\hline \multirow{2}{*}{ totalgdsubsi } & $0.1966^{\star}$ & 0.361 & 0.598 & $0.5091^{\star}$ & $0.209^{\star *}$ \\
\hline & $(0.109)$ & $(0.263)$ & $(0.482)$ & $(0.277)$ & $(0.083)$ \\
\hline \multirow{2}{*}{ totaldhsubsi } & $43.29^{\star *}$ & $30.41^{\star \star}$ & 31.9 & 17.9 & $59.95^{\star *}$ \\
\hline & $(17.6)$ & (13.68) & $(37.5)$ & (16.75) & $(28.9)$ \\
\hline \multirow{2}{*}{ nongjisubsi } & $416.9^{* *}$ & $291.8^{\star \star}$ & 126.32 & 174.6 & $258.1^{\star}$ \\
\hline & $(162.52)$ & (130.3) & $(235.77)$ & $(159.57)$ & $(138.93)$ \\
\hline \multirow{2}{*}{ otherplants } & $-0.0860^{\star}$ & -0.0748 & -0.0611 & -0.0406 & $-0.0497^{\star * *}$ \\
\hline & $(0.0498)$ & $(0.062)$ & $(0.0627)$ & $(0.0517)$ & $(0.011)$ \\
\hline \multirow{2}{*}{ constant } & $10.44^{\star * \star}$ & $-8.314^{\star \star \star}$ & $9.443^{* * *}$ & $11.13^{* * *}$ & $9.765^{\star * *}$ \\
\hline & $(1.884)$ & $(1.725)$ & $(2.525)$ & $(1.856)$ & $(2.093)$ \\
\hline$R^{2}$ & 0.6622 & 0.5593 & 0.6737 & 0.7073 & 0.6702 \\
\hline$N$ & 418 & 418 & 235 & 235 & 418 \\
\hline
\end{tabular}

Notes: Standard errors of coefficients are reported in ()$,{ }^{\star} p<0.10,{ }^{\star *} p<0.05,{ }^{\star * \star} p<0.01$. 


\subsection{Instrumental variable test}

The two-stage square method (2SLS) was utilized to determine the exogenous instrumental variables and then avoid the possible endogeneity. In this paper, the core explanatory variable "Whether farmers to urban sectors to work temporarily (jiianyeor)" could be explained by the instrumental variable "Whether have ever been engaged in any other profession before? (otherjobor)". Reasons for the alteration are as follows: Firstly, data in this paper was sampled in 2018. Then the agricultural labor productivity of farmer households was primarily affected by input factors (including labor, capital and technology factors) of the current year. Thus it's uncertain whether farmers had been engaged in other occupations before (in the year of 2017 and before) does not directly affect the latest productivity of farmer households, nor does it has significant correlations with other control variables in 2018. Besides, the skillful experience from previous non-agricultural working enable farmers to participate the nonagricultural part-time work, that is the direct influences of otherjobor on jiianyeor would indirectly affect the agricultural productivity labor of of farmer households. Therefore, the instrumental variable otherjobor satisfies the hypothesis of correlation and exclusivity, and is a more suitable instrumental variable. In this paper, the core explanatory variable jiianyeor was further interpreted by the instrumental variable otherjobor with the credibility proved by successive empirical tests.

With the first column in Table 2 and the exogenous instrumental variable otherjobor, the first column in Table 3 was obtained with two-stage least square method (2SLS). Furthermore, two stage generalized method of moments (2SGMM) was adopted to examine results in the first column via the regression analysis to obtain the second column in Table 3. Moreover, we utilized the two stage limited information maximum likelihood estimation (2SLILM) to lower effects of weak instrument variable and then obtain the third column in Table 3.

From Table 3, results of the third column were completely consistent with those of the first column. Then the problem of weak instrumental variable is negligible. In addition, the value of kleibergen-paap Wald rk F statistic was 26.38, significantly higher than the critical value $(16.38 ; p<0.1)$, further confirming that weak instrumental variable about the exogenous instrumental variable could be neglected in this paper. Results of the second column were completely in accordance with the first column, indicating the insignificant heteroscedasticity during the econometric regression. Meanwhile, the value of $F$ test was 4.48 $(p<0.05)$, demonstrating effectiveness of the instrumental variable selected in this paper, and the value of Kleibergen-paap rk LM statistic was $4.64(p<0.05)$, revealing that the unrecognizable original hypothesis should be strongly rejected while the instrumental variable was highly correlated with endogenous explanatory variable. On the whole, instrumental variable selected in this paper was proven effective.

Moreover, regression results of the first stage by 2SLS method was listed in the upper half of the Table 3. According to the relevant coefficients about the core explanatory variable in the second stage, it's evident that the non-agricultural part-time work of the large farmer households still conduce to the improvement of agricultural labor productivity even considering the interference of endogenous problems. 
Table 3. The regression results of 2 SLS

\begin{tabular}{|c|c|c|c|}
\hline \multirow{2}{*}{$\begin{array}{l}\text { The first stage regression } \\
\text { (jianyeor) }\end{array}$} & (1) & (2) & (3) \\
\hline & 2SLS & 2SGMM & 2SLIML \\
\hline \multirow{2}{*}{ otherjob } & $0.1045^{\star *}$ & $0.1045^{\star *}$ & $0.1045^{\star \star}$ \\
\hline & $(0.0493)$ & $(0.0493)$ & $(0.0493)$ \\
\hline Other variables & Yes & Yes & Yes \\
\hline \multirow{2}{*}{ F test } & 4.48 & 4.48 & 4.48 \\
\hline & {$[0.0348]$} & {$[0.0348]$} & {$[0.0348]$} \\
\hline$N$ & 418 & 418 & 418 \\
\hline \multicolumn{4}{|c|}{ The second stage regression (ln falacity) } \\
\hline \multirow{2}{*}{ jianyeor } & $0.194^{* * *}$ & $0.194^{\star * *}$ & $0.194^{\star * *}$ \\
\hline & $(0.051)$ & $(0.051)$ & $(0.051)$ \\
\hline Control variables & Yes & Yes & Yes \\
\hline \multirow{2}{*}{ constant } & $6.396^{*}$ & $6.396^{*}$ & $6.396^{*}$ \\
\hline & $(3.457)$ & $(3.457)$ & $(3.457)$ \\
\hline$R^{2}$ & 0.4168 & 0.4168 & 0.4168 \\
\hline$N$ & 418 & 418 & 418 \\
\hline \multirow{2}{*}{ Kleibergen-Paap rk LM statistic } & 4.64 & 4.64 & 4.64 \\
\hline & {$[0.0313]$} & {$[0.0313]$} & {$[0.0313]$} \\
\hline $\begin{array}{l}\text { Kleibergen-Paap Wald rk F } \\
\text { statistic }\end{array}$ & 26.47 & 26.47 & 26.47 \\
\hline
\end{tabular}

Notes: Standard errors of coefficients are reported in ()$,{ }^{*} p<0.10,{ }^{* *} p<0.05,{ }^{* *} p<0.01 ; P$ values are reported in []; the critical value of $F$ statistic is 16.38 at the $10 \%$ level of significance.

\subsection{Analysis of influential mechanism}

Theoretically, non-agricultural part-time work of large farmer households enhances the productivity via entering the agricultural association, increasing farm mechanization degree, and promoting the centralized production and farm management on the transferred farmland. Further, we use the micro-survey data from 418 farmer households in Hunan province, central China to demonstrate the above working mechanisms by rigorously screening the proxy variables. Firstly, two indicators were utilized to represent the labor specialization of agricultural production, i.e. "centralized production" $(C P)$ and "family-based farm management". Secondly, the economic organization of agricultural production was characterized by “joining agricultural association". Finally, "improving mechanization degree" was selected to denote the roundabout production.

First, the non-agricultural part-time work of the large farmer households generated demands for spontaneously constructing and joining agricultural association, which significantly improved the productivity of farmer households through optimizing and integrating the distribution of producing factors within the association. Then the ordinary least square method (OLS) was utilized by taking jiianyeor as the explanatory variable (the same below) and groupor as the explained variable, and controlling other influential factors. Results were 
detailed in the first column in Table 4, among which the coefficient estimated on jiianyeor was $0.137(p<0.05)$, indicating that the non-agricultural part-time work of the large farmer households objectively strengthened their demands for joining agricultural cooperative association, contributing to the improvement of agricultural productivity. Agricultural mechanization would facilitate the labor division and specialization. Although there were no adaptive indicators specified in the questionnaire to directly measure the mechanization level of agricultural production, it could be indirectly measured in terms with the amount of fiscal subsidies for purchasing the agricultural machinery by large-scale farmer households. By measuring the mechanization level of agricultural production from nongjisubsi, regression results of the second column in Table 4 by repeating the regression process of the first column were obtained, among which the estimated coefficient of iianyeor was $0.274(p<0.10)$, suggesting that the non-agricultural part-time work objectively enhanced the agricultural mechanization and then the agricultural productivity. When compared with the demands of groupor and jtnchangor by the respective estimated coefficients, it's evident that the demand for mechanization of agricultural production, as reflected by nongjisubsi, was the highest for the non-agricultural part-time work of the large farmer households $(0.274>0.137>0.0886)$. During the process of implementing policies on agricultural production, the mechanization of agricultural production is one of the most important strategies to realize the scale development of agricultural production in China.

As with the transferred farmlands, the non-agricultural part-time work would motivate large-scale farmer households to select the concentrated ones, then promoting the centralized and scaled management for agricultural production (He et al., 2016). Therefore, by taking landkshu as the explained variable, results in the third column of Table 4 was acquired after repeating the regression process of the former two columns. Estimated coefficient about the core explanatory variable was $-1.972(p<0.05)$, indicating that farmers who joined the non-agricultural part-time work were liable to select the centralized production on the transferred farmlands and reduce the spatial dispersion of the arable lands of certain rural family, then improving the agricultural productivity. Farm management could efficiently realize the transformation of agricultural production from traditional small-scale to modern intensive large-scale (Zhao \& Jiang, 2015). By taking jtnchangor as the explained variable, results of the

Table 4. Analysis of influential mechanism on agricultural labor productivity

\begin{tabular}{|l|c|c|c|c|}
\hline \multirow{2}{*}{} & $(1)$ & $(2)$ & $(3)$ & $(4)$ \\
\cline { 2 - 5 } & groupor & nongjisubsi & landkshu & jtnchangor \\
\hline \multirow{2}{*}{ jianyeor } & $0.137^{\star *}$ & $0.274^{\star}$ & $-1.972^{\star *}$ & $0.0886^{* *}$ \\
\cline { 2 - 5 } & $(0.0537)$ & $(0.142)$ & $(0.830)$ & $(0.0435)$ \\
\hline Other variables & Yes & Yes & Yes & Yes \\
\hline \multirow{2}{*}{ constant } & $0.706^{* * *}$ & $1.45^{\star *}$ & $-9.983^{\star *}$ & $1.384^{\star *}$ \\
\cline { 2 - 5 } & $(0.171)$ & $(0.593)$ & $(4.10)$ & $(0.512)$ \\
\hline$R^{2}$ & 0.4405 & 0.5278 & 0.4219 & 0.3831 \\
\hline$N$ & 418 & 418 & 418 & 418 \\
\hline
\end{tabular}

Notes: Standard errors of coefficients are reported in ()$,{ }^{*} p<0.10,{ }^{* *} p<0.05,{ }^{* *} p<0.01$. 
fourth column in Table 4 was assessed by repeating regression process of the former three columns, where the estimated coefficient on jiianyeor was $0.0886(p<0.05)$, indicating that certain positive driving force for demands was generated due to the non-agricultural parttime work to stimulate the farmer households to implement scale operation of agricultural production even though the relatively-smaller driving force of the demands.

\subsection{Heterogeneity analysis}

Total area of farmland is one of the most important factors affecting the farmer households to join the non-agricultural part-time work. According to the descriptive statistic about the area of farmers' family-owned and -transferred farmlands, it's observable that the area of transferred farmland exhibited the predominance over the total farmland area of large-scale farmer households. It's reasonable to represent the size of the transferred farmland by the total farmland area, reflecting the prosperity in the current farmland transfer market. Hence, the total farmland area of certain farmer households was divided into five interval groups (Table 5). For each group, data of the fifth column in Table 5 was calculated by taking "In falacity" as the explained variable and "jianyeor" as the core explanatory variable and controlling other relevant influential factors for econometric regression. From the five estimated coefficients on the core explanatory variables, farmer households with total farmlands area less than $500 \mathrm{Mu}$ referred to those involved in the non-agricultural part-time work increase amplitude of the agricultural labor productivity ranked with total farmland area in the range of $(100,200) \mathrm{Mu}<(200,300) \mathrm{Mu}<(0,100) \mathrm{Mu}<(300,500) \mathrm{Mu}$. Meanwhile, the nonagricultural part-time work inhibit the improvement of the agricultural labor productivity of farmer households with total farmland area larger than $500 \mathrm{Mu}$.

In consistency with Zhao and Jiang (2015) and Chamberlin and Jayne (2020), we recommended that the total farmland area of farmer households should be maintained within a certain range to avoid the reverse effects. And the optimal area of total farmlands should be within the range of $(100,200] \mathrm{Mu}$ to facilitate the farmer households exert the comparative advantage of abundant labor force, realize agricultural mechanization production and optimize the resource integration through joining the agricultural cooperative association, fundamentally promoting the agricultural labor productivity.

Table 5. Grouping heterogeneity regression results of total farmland area of farmer households

\begin{tabular}{|l|c|c|c|c|c|}
\hline \multirow{2}{*}{} & $(1)$ & $(2)$ & $(3)$ & $(4)$ & $(6)$ \\
\cline { 2 - 6 } & $(0,100]$ & $(100,200]$ & $(200,300]$ & $(300,500]$ & $(500,1200]$ \\
\hline \multirow{2}{*}{ jianyeor } & $0.217^{\star}$ & $0.374^{\star *}$ & $0.225^{\star * \star}$ & $0.171^{\star}$ & $-0.0111^{\star * *}$ \\
\cline { 2 - 6 } & $(0.127)$ & $(0.154)$ & $(0.0752)$ & $(0.0948)$ & $(0.0041)$ \\
\hline Other variables & Yes & Yes & Yes & Yes & Yes \\
\hline \multirow{2}{*}{ Constant } & $8.890^{\star * \star}$ & $14.62^{\star * *}$ & $18.83^{\star * \star}$ & $7.407^{\star * *}$ & $13.66^{\star}$ \\
\cline { 2 - 6 } & $(2.297)$ & $(4.003)$ & $(6.045)$ & $(2.314)$ & $(7.573)$ \\
\hline$R^{2}$ & 0.6875 & 0.5487 & 0.7632 & 0.8313 & 0.7026 \\
\hline$N$ & 210 & 98 & 42 & 31 & 37 \\
\hline
\end{tabular}

Notes: Standard errors of coefficients are reported in ()$,{ }^{*} p<0.10,{ }^{* *} p<0.05,{ }^{* *} p<0.01$. 
In addition, impacts of age on the agricultural labor productivity profiled in the humpedshape with the inflection point of 47.3 years (Table 2). Then all the samples were divided into two groups with the threshold age of 50 years to analyze how the non-agricultural part-time work of the large farmer households affected the agricultural labor productivity. From results of the first two columns in Table 6, farmers younger than 50 years tended to join the nonagricultural part-time work in comparison with those older than 50 years and then obviously affect the agricultural productivity. Generally, young migrant farmers are well-educated ones and prone to receive the spillover effects of knowledge and science-technology from the targeted regions, then raising their willingness and capacity to improve the agricultural technology and productivity. Thus all the samples were re-grouped according to the education experience of farmer households. Results showed that the non-agricultural part-time work would more significantly improve the agricultural labor productivity for farmers with high school education or above than those with middle school or below (Table 2). Furthermore, we hypothesized that the non-agricultural part-time work of the large farmer households was affected by the number of labor force engaged in agricultural production. By re-arranging the samples according to the number of labor force, farmers from farmer households with less than two persons engaged in agricultural production (noyer $\leq 2$ ) were not prone to participate in the non-agricultural part-time work. The enhancement of the agricultural productivity would be significantly inhibited on the basis of the sizeable area of farmlands. In contrast, for those from farmer households with more than three engaged in agricultural production, the non-agricultural part-time work was conducive to the improvement of the agricultural labor productivity, suggesting that there is a certain proportion of producing factors between the number of labor force engaged in agricultural production and the arable land area of farmer households (Coase, 1990; Wang et al., 2017).

Table 6. Grouping heterogeneity regression results of different influence factors

\begin{tabular}{|c|c|c|c|c|c|c|}
\hline & (1) & (2) & (3) & (4) & (5) & (6) \\
\hline & age $<=50$ & age $>50$ & education $<=3$ & education $>3$ & noyerk $<=2$ & noyerk $>2$ \\
\hline \multirow{2}{*}{ jianyeor } & $0.274^{\star \star}$ & $0.187^{\star *}$ & $0.109^{*}$ & $0.275^{\star \star \star}$ & $-0.0136^{\star * *}$ & $0.230^{\star *}$ \\
\hline & $(0.113)$ & $(0.063)$ & $(0.063)$ & $(0.096)$ & $(0.0033)$ & $(0.103)$ \\
\hline Other variables & Yes & Yes & Yes & Yes & Yes & Yes \\
\hline \multirow{2}{*}{ Constant } & 4.589 & $13.46^{\star *}$ & $9.961^{* * *}$ & $9.570^{* *}$ & $10.65^{\star * *}$ & $9.727^{\star * \star}$ \\
\hline & $(3.680)$ & $(6.564)$ & $(2.630)$ & $(4.013)$ & $(2.476)$ & (3.143) \\
\hline$R^{2}$ & 0.6563 & 0.6953 & 0.6653 & 0.7109 & 0.6825 & 0.7472 \\
\hline$N$ & 188 & 230 & 293 & 125 & 288 & 130 \\
\hline
\end{tabular}

Notes: Standard errors of coefficients are reported in ()$,{ }^{\star} p<0.10,{ }^{* *} p<0.05,{ }^{* *} p<0.01$. 


\section{Conclusions and policy implications}

This study uses micro-survey data of 418 farmer households from 7 counties of Hunan province, central China, and analyzes the mechanism of coexistence of non-agricultural part-time work of farmer households and large-scale cultivation of cultivated land, and the effect of non-agricultural part-time work of the large farmer households on the agricultural labor productivity. The instrumental variable method and a series of robustness checks were adopted to further alleviate the endogenous problem and verify the credibility of the conclusion.

Our theoretical and econometric analysis show that the non-agricultural part-time work of farmer households and family-based large scale management of farmland can co-exist, in particular, as the farmland area of rice growers has been considerably expanded due to the transferring market mechanism, the proportion of peasants involved in the non-agricultural part-time work still accounts for $56.22 \%$. Besides, non-agricultural part-time work of the large farmer households promote the agricultural labor productivity, particularly for those with higher non-agricultural incomes and/or shorter distance between working places in urban sectors and rural residence. These results remain consistent after we experiment several robustness checks and the instrumental variable method. Further, younger farmers and/or those with higher education level more significantly improve the agricultural labor productivity when selecting the non-agricultural part-time work in cities. It is worth stressing that non-agricultural part-time work inhibits the agricultural production for of farmer households with labors less than three, while it exhibits positive effects for those with labors more than three. Finally, analysis of mechanism suggests that non-agricultural part-time work of large farmer households enhances the productivity via entering the agricultural association, increasing farm mechanization degree, and promoting the centralized production and farm management on the transferred farmland.

The conclusion of this study carries clear-cut policy implication. From the heterogeneity analysis on influential factors, it's recommendatory that optimal value of total farmland area should be maintained within the range of $(100,200) \mathrm{Mu}$. Thus the government should formulate the threshold of fiscal subsidies conforming to the quota of fiscal subsidy to support the large-scale farmer households in agricultural production and actively guide arable lands transferred at appropriate scales. While for farmers younger than 50 years old and/or receiving education from high school or above, the non-agricultural part-time work would remarkably promote the agricultural labor productivity of farmer households. Hence the government should strengthen the working capacity of young farmers involved in the nonagricultural part-time work by introducing advanced agricultural production technology and management ideas. Besides, as with farmer households with less than two labor force engaged in agricultural production, the part-time working would evidently inhibit the agricultural productivity due to the sizeable area of farmlands, which is reversed for those with more than two labor force owing to the farm management. It's inadvisable for farmers from farmer households possessing larger transferred farmland but insufficient labor force to join the non-agricultural part-time work and suppress the agricultural labor productivity. Last, non-agricultural part-time work of the large farmer households would significantly improve the agricultural labor productivity when they travelled short distance from rural residence 
to workplace in the urban. Therefore, Local and nearby urban regions should be equipped with crucial employment supporting industries and better public infrastructures to motivate the non-agricultural part-time work of the large farmer households.

According to the test results of working mechanisms, it's imperative for farmers engaged in the non-agricultural part-time work to establish and join the associations to optimize the allocation of producing materials and promote the agricultural productivity. And it's of importance for the government to stimulate the innovation of agricultural science and technology and the technological upgrade of agricultural machinery manufacturing. Correspondingly, financial incentives and regulatory policies should be proposed to efficiently implement the centralized agricultural production and farm management on the transferred farmlands.

\section{Acknowledgements}

The authors gratefully acknowledge the financial supports from the National Natural Science Foundation of China (71473134), National Social Science Foundation of China (20BGL201, 18BRK032), the Research Foundation of Education Bureau of Hunan Province, China (19A181) and Fundamental Research Funds for the Central Universities (CXJJ-2018-361).

\section{Conflicts of interest}

The authors declare no conflicts of interest.

\section{References}

Chamberlin, J., \& Jayne, T. S. (2020). Does farm structure affect rural household incomes? Evidence from Tanzania. Food Policy, 90, 101805. https://doi.org/10.1016/j.foodpol.2019.101805

Coase, R. H. (1990). Accounting and the theory of the firm. Journal of Accounting and Economics, 3, 3-13. https://doi.org/10.1016/0165-4101(90)90038-6

El Omari, S. (2017). Sticky price models of the business cycle: Can the roundabout production solve the persistence puzzle? Economics Letters, 160, 67-72. https://doi.org/10.1016/j.econlet.2017.08.028

Gai, Q. G., Zhu X., Cheng, M. W., \& Shi, Q. H. (2017). Land misallocation and aggregate labor productivity. Economic Research Journal, 5, 119-132.

Gao, F. (2015). International experience to improve agricultural labor productivity and China's choice. Fudan Journal (Social Science Edition), 1, 116-124.

Glaeser, E. L. (Ed.). (2010). Agglomeration economics. University of Chicago Press. https://doi.org/10.7208/chicago/9780226297927.001.0001

He, X., Jiang, T., Guo, L. Y., \& Gan, L. (2016). The study on the market development of Chinese farmland transferring and the behavior of farmland transferring of farmers-based on the survey data of farmers in 29 provinces from 2013 to 2015. Management World, 6, 79-89.

Huang, Q., Jiang, X., \& Xiang, G. C. (2018). Does the development of private economics enlarge urbanrural income gap. Modern Economic Science, 1, 13-25.

Huang, Y. P. (2003). Agricultural management system and division of labor on the basis of specialization-concurrently discusses household management and large-scale production. Issues in Agricultural Economy, 6, 50-55. 
Jiang, X., \& Huang, Q. (2019). The study on the changing trend of aging and the productivity of labor. Contemporary Economic Research, 3, 83-95.

Kawagoe, T., Hayami, Y., \& Ruttan, V. W. (1985). The inter-country agricultural production function and productivity differences among countries. Journal of Development Economics, 19(1-2), 113-132. https://doi.org/10.1016/0304-3878(85)90041-0

Lewis, W. A. (1954). Economic development with unlimited supplies of labour. The Manchester School, 22(2), 139-191. https://doi.org/10.1111/j.1467-9957.1954.tb00021.x

Liang, Q., Chen, Q. Y., \& Wang, R. Y. (2013). Household registration reform, labor mobility and optimization of the urban hierarchy. Social Sciences in China, 12, 36-59.

Liu, R. M., \& Shi, L. (2010). The dual efficiency loss of state-owned enterprises and economic growth. Economic Research Journal, 1, 127-137.

Liu, R. M., \& Shi, L. (2015). The basis of ownership of china's retardant urbanization: Theory and empirical evidence. Economic Research Journal, 4, 107-121.

Lu, M., Gao, H., \& Zuo, T. H. (2012). On urban scale and inclusive employment. Social Sciences in China, 10, 47-66.

Ma, W., Abdulai, A., \& Ma, C. (2018). The effects of off-farm work on fertilizer and pesticide expenditures in China. Review of Development Economics, 22(2), 573-591. https://doi.org/10.1111/rode.12354

Narayan, P. K., \& Sun, G. Z. (2007). The division of labor, capital, communication technology and economic growth: The case of China 1952-99. Review of Development Economics, 11(4), 645-664. https://doi.org/10.1111/j.1467-9361.2007.00393.x

Nguyen, D. L., Grote, U., \& Nguyen, T. T. (2019). Migration, crop production and non-farm labor diversification in rural Vietnam. Economic Analysis and Policy, 63, 175-187. https://doi.org/10.1016/j.eap.2019.06.003

Qian, Z. H. (2003). The market liquidity of contracting and operating right to rural land: A theoretical and empirical study. Economic Research Journal, 2, 83-91.

Qin, Y., \& Zhang, X. (2016). The road to specialization in agricultural production: Evidence from rural China. World Development, 77, 1-16. https://doi.org/10.1016/j.worlddev.2015.08.007

Qiu, T., Choy, S. B., Li, S., He, Q., \& Luo, B. (2020). Does land renting-in reduce grain production? Evidence from rural China. Land Use Policy, 90, 104311. https://doi.org/10.1016/j.landusepol.2019.104311

Ranis, G., \& Fei, J. C. (1961). A theory of economic development. American Economic Review, 4, 533-565.

Tang, J., Zhong, S. H., \& Xiang, G. C. (2019). Environmental regulation, directed technical change, and economic growth: Theoretic model and evidence from China. International Regional Science Review, 42(5-6), 519-549. https://doi.org/10.1177/0160017619835901

Todaro, M. P. (1969). A model of labor migration and urban unemployment in less developed countries. American Economic Review, 1, 138-148.

Wang, X., Yamauchi, F., \& Huang, J. (2016). Rising wages, mechanization, and the substitution between capital and labor: Evidence from small scale farm system in China. Agricultural Economics, 47(3), 309-317. https://doi.org/10.1111/agec.12231

Wang, Y. H., Li, X. B., Xin, L. J., Tan, M. H., \& Li, W. (2017). The impact of farm land management scale on agricultural labor productivity in China and its regional differentiation. Journal of Natural Resources, 32(4), 539-552.

Xiang, G. C., \& Han, S. F. (2005). Part-time peasant households: Analysis based on the perspective of division of labor. Chinese Rural Economy, 8, 4-9. 
$\mathrm{Xu}$, J. Y. (1995). The necessity of developing moderate scale operation in agriculture and its restrictive conditions. Development Research, 6, 18-24.

$\mathrm{Xu}, \mathrm{Y}$. (2010). The extension of the rationalism of the peasantry: An analysis of the key actors behind the China miracle-a challenge to the existing theories and a new analytical framework. Social Sciences in China, 1, 103-118.

Yang, X. K. (1994). Endogenous vs. exogenous comparative advantages and economics of specialization vs. economies of scale. Journal of Economics, 60, 29-54. https://doi.org/10.1007/BF01228024

Yang, X. K. (2003). New classical economics and infra-marginal analysis. Social Sciences Academic Press.

Young, A. (1928). Increasing returns and economic progress. Economic Journal, 38, 527-542. https://doi.org/10.2307/2224097

Zhang, S. G. (2010). Farmland transferring and agricultural modernization. Management World, 7 , 66-85.

Zhang, W. Y. (2014). The power of ideas: What will determine China's future? Northwestern University Press.

Zhao, B. H. (2014). Analysis on the scale operation of farmland under the background of part-time job of farmers in China. Truth Seeking, 11, 91-96.

Zhao, J., \& Jiang, C. Y. (2015). Concurrent business agricultural household or family farm? Path choice of organizational evolution of agricultural household management in China. Issues in Agricultural Economy, 3, 11-18.

Zhao, S. C., Xu, Q., \& Liu, J. (2020). Labor migration, capital deepening, and agricultural land circulation in China. Journal of Agrotechnical Economics, (03), 4-19.

Zhong, F., Lu, W., \& Xu, Z. (2016). Does rural off-farm employment go against grain production? Analysis of the substitution of household elements and the adjustment of grain-crop structure and constraint conditions. Chinese Rural Economy, 22(07), 36-47.

Zou, X. S. (2005). The agents of migrant workers' flowing to cities: A realistic interpretation of the theory of "push and pull". Rural Economy, 10, 104-109. 